\title{
HUMAN CAPITAL AND SOCIAL CAPITAL IN ENTREPRENEURS AND MANAGERS OF SMALL AND MEDIUM ENTERPRISES
}

\author{
J. Augusto Felício ${ }^{1}$, Eduardo Couto ${ }^{2}$, Jorge Caiado ${ }^{3}$ \\ ${ }^{1,2}$ ISEG, School of Economics and Management, Technical University of Lisbon, \\ Rua Miguel Lupi, 20, 1249-078 Lisbon, Portugal \\ ${ }^{3}$ CEMAPRE, Centre for Applied Mathematics and Economics, \\ Instituto Superior de Economia e Gestão, Technical University of Lisbon, \\ Rua do Quelhas, 6, 1200-781 Lisbon, Portugal

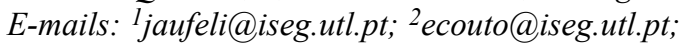 \\ 3jcaiado@iseg.utl.pt (corresponding author)
}

Received 26 January 2011; accepted 01 June 2011

\begin{abstract}
This paper uses factor analysis methods to identify structures associated with human and social capital in a small country with an open-economy, based on a survey of small- and medium-sized companies across different sectors. The purpose of this research is to investigate the influences of entrepreneurial and managerial behaviours on the relationship between human capital and social capital. The results indicate that the principal factor is highly correlated to the variables of experience, professional proficiency and cognitive ability, which are predominant characteristics of the entrepreneur, as well as status variables such as interlinking, family support, personal relations and social relations. The study also suggests that links between human capital and social capital are more salient in manufacturing and construction companies than in the wholesale trade, retail trade and services sectors.
\end{abstract}

Keywords: human capital, social capital, small and medium enterprises, factor analysis.

Reference to this paper should be made as follows: Felício, J. A.; Couto, E.; Caiado, J. 2012. Human capital and social capital in entrepreneurs and managers of small and medium enterprises, Journal of Business Economics and Management 13(3): 395-420.

JEL Classification: C38, L26, L60, L74, L81, M19.

\section{Introduction}

The elements of human capital (e.g. Hambrick, Mason 1984; Bantel, Jackson 1989; Becker 1993) and social capital (e.g. Bourdieu 1986; Coleman 1988; Burt 1992; Putnan 1995; Walker et al. 1997) traditionally refer to large and mature institutions and organisations. Nahapiet and Ghoshal (1998) helped prompt the spread of social capital in the literature focusing on organisational studies. Despite their economic and social relevance, there have been few studies in the literature regarding the relationship between human capital and social capital in small and medium enterprises (SMEs). In these companies, entrepreneurial action leading to successful management relies on 
human and social capital. According to Anderson (2000), business processes result, to a large extent, from the dynamics of the individual, the contingency of many of its connections and the influence of its contexts. In addition, organisations are composed of multilevel systems of social capital that integrate processes occurring at individual, group and organisational levels (Leana, Van Buren 1999; Klein, Kozlowski 2000).

Schwartz (1990), Triandis (1993) and Tiessen (1997) have shown the effects of individualism and collectivism on entrepreneurship, although no consensus has been found on which are the most suitable cultures for entrepreneurship growth in distinct environments. In terms of social capital Pyke, Sengenberger (1992) have analyzed the industrial districts as examples of small and medium enterprise organization given the importance of the sociological concept of region to explain the competitive advantages of the companies located in those industrial districts (Lazerson 1995) towards economic success (Brusco 1982).

Human capital refers to a set of characteristics that provide individuals with more skills, namely, cognition, experience and knowledge, which make them more productive, provide a higher potential for efficiency and enhance the development of activities (Becker 1964; Mincer 1974). In the business perspective, for example, Bates (1995) and Shane and Venkataraman (2000) have highlighted that individuals with higher levels of human capital have a higher propensity for entrepreneurial activity as a result of greater levels of self-confidence and decreased concerns over risk.

Social capital focuses on the fitness of the players and their personal relationships (Lin et al. 1981; Portes 1998). It relates to a composite of social obligations or connections that is convertible into economic capital under certain conditions and involving different entities. Social capital serves as a facilitator of social structure for certain actions of individuals, which benefit both the individuals and the organisations (Bourdieu 1986; Coleman 1990; Putnan 1995). It mainly deals with interactions between people.

According to Kilduff and Tsai (2003), social capital may be defined at the individual level or collective level, the latter of which includes groups, firms, communities and/or nations. This perspective raises the discussion of social capital at the level of individuals (Burt 1992), organisations (Leana, Van Buren 1999), institutions (Putnan 1995) and industries (Walker et al. 1997). This multilevel approach seeks to integrate and explore how the different properties of exchange networks influence individual development.

Different authors (Pennings et al. 1998; Gimeno et al. 1997; Nahapiet, Ghoshal 1998; Adler, Kwon 2002) show extensive literature on the relationship between human capital and social capital but accentuate little knowledge about the types of relations in a specific industry or activity. Specifically, they do not clarify whether the types of relations, ties and connections are similar or different across different industries. Other authors (Coleman 1988; Bates 1995, Nahapiet, Ghoshal 1998; Bruderl, Preisendorfer 1998; Florin et al. 2003; Lester et al. 2008) also consider insufficient knowledge of the influences of social structure on human capital. Moreover, it is unclear whether greater importance of social capital is due to the network of interconnections (positive externalities) or to social status (negative externalities) (Glaeser et al. 2002). 
The focus of this study is to evaluate the relationship between human capital and social capital for entrepreneurs and managers of small- and medium-sized companies. What types of elements of human capital are interlinked with elements of social capital? Does business or industry render different influences on the relationship between various elements of human capital and social capital? A factor analysis technique was used to identify the structure of relationships between the variables of social capital and human capital and to ascertain the influences of the business sector on this relationship.

In this article, Section 2 presents a literature review and hypothesis development. Section 3 provides the data and presents a brief description of the statistical methodology. Section 4 reports the empirical findings. Section 5 discusses the results. Finally, Section 6 concludes and offers proposals for future research.

\section{Literature review and hypotheses}

Becker (1964) and Coleman (1988) identify human capital as the expertise, experience, knowledge, reputation and skills of an individual and social capital as the potential that available resources provide as a result of a network of relationships between individuals. The concept extends to collective social capital (Leana, Van Buren 1999; Putnan 1995), which reflects the degree of social integration and values shared within an organisation and also involves and benefits not only individuals but also organisations (Portes, Sensenbrenner 1993).

Human capital has been considered critical to entrepreneurial activity, especially in obtaining specific resources (Brush et al. 2001), by facilitating access to social and influential relations of great utility, which then contributes value and importance of informal contacts (Glaeser et al. 2002; Brinlee et al. 2004). It refers to individuals who possess knowledge, skills and abilities acquired through education, training and experience (Bruderl et al. 1992; Becker 1993; Gimeno et al. 1997). Human capital is an individual-level resource that includes accumulated experiences, skills, education and other forms of knowledge (Becker 1993).

The essence of social capital (Bourdieu 1986; Coleman 1990; Putnan 1995) is the network of relationships that include family, friends and casual relationships as suppliers of important resources of knowledge, information and support. It is an asset associated with the structure inherent in social relations and networks (Burt 1997) that facilitate individual action (Lin et al. 1981; Tsai, Ghoshal 1998). The importance of social networks lies in the social structure and is based on individuals, groups, institutions and social interactions (Wasserman, Faust 1994), under which, according to Degenne and Forsé (1999), "individuals cannot be studied independently of their relations to others, nor can dyads be isolated from their affiliated structures".

The literature has focused on the effects of individualism and collectivism on entrepreneurship (Triandis 1993; Tiessen 1997) although there are some authors that consider collectivism a barrier to entrepreneurship development. Entrepreneurs usually have a propensity towards individualism (Huisman 1985; Scheinberg, MacMillan 1986). 
Nevertheless, the results of some empirical studies show that, in certain contexts with more collectivist cultures, as is the case of some Asian (Bond 1991) or Scandinavian countries (Peterson 1988) have led, in certain periods, to a bigger positive impact on economic development. Other studies show that there is an equilibrium between individualism and collectivism cultures (Morris et al. 1994; Hofstede 1991).

Furthermore, according to Kecharananta and Baker (1999) the interdependence between people and their contributions to the organizations is quite real. The individual actions should be integrated and articulated with the organizations in order to obtain higher effectiveness levels. The concept of "social capital" is, in some way, related to collectivism (Fukuyama 1995).

Anderson and Miller (2003) ascertained that the nature and extent of social capital and resources from the social network affect the ability of the entrepreneur to recognise and pursue opportunities provided by certain businesses. Glaeser et al. (2002), in referring to the individual social capital, associate it with the social features that allow the entrepreneur or manager to reap the benefits of personal interactions in the market and in society. These business networks at the individual level focus on the relationships or ties of entrepreneurs with other individuals and organisations as players in the firm (Anderson, Miller 2003), equipping each employer or manager with a unique set of attributes and resources for the company (Kosnik 1990). However, the relational ties may differ depending on the characteristics of the social interactions (Hite 2003), creating the potential for evolution in a social network via opportunities to discover business and resource mobilisation. On this subject, Bourdieu (1986) highlights the fact that economic capital identified with the ownership of assets, resources or attributes and accumulated with investment potential is the basis for all other types of capital. Economic capital interacts with other forms to influence social structures, as social life is like a multi-dimensional game in which individuals utilise their economic, social, cultural and capital resources to obtain status. He also emphasised that individuals from higher socio-economic status groups are likely to have more human capital, are more prone to social contacts and have the most effective support of these groups. Such findings lead Durlauf and Fafchamps (2005) to discuss the difficulty in separating individual effects from the combined effects of social capital. Given the importance of the interactions and ties at various levels, including individuals, undifferentiated groups or organisations, the horizontal or vertical connections that are part of the aforementioned multilevel approach are significant. In this framework, De Wever et al. (2005) considers social capital to be multidimensional and proposes an analytical model of its influence on the efficiency of interorganisational networks. Oh et al. (2004) consider these networks multilevel models of relationships within and among groups to identify how these relationships can be extended to elements of the network to improve group efficiency. They consider the social capital of the group to be just as important as each of its elements. According to Oh et al. (2006), the social capital of the group refers to the set of available resources derived from the social relations of its members within the social structure of the group itself as well as in both formal and information structures of the organisation. It is thought to be a meta-analysis, which in turn is composed of a set of 
resources that flow from the attitudes of the relationships and configurations of these own attitudes (Seibert et al. 2001).

The literature recognises groups or organisations as social systems qualitatively different from individuals whose interactions are different at both macro and micro levels. The macro level considers interactions to be concentrated in clusters or collective behaviours, while ignoring those that occur at the individual level. The interactions at the micro level fit into a macro context and result from the interaction and dynamics of elements at lower levels.

Another important issue relates to the importance of the industrial districts for the small and medium enterprises in different perspectives and implications for economic success (Pyke, Sengenberger 1992; Becchetti, Rossi 2000). Several authors (McNaughton, Bell 1999; Gulati 1999; Davidsson, Honig 2003; Van Dijk, Sverrisson 2003; Lechner, Dowling 2003; Wolfe, Gertler 2004) have shown the great importance of inter-company cooperation and economic factors, values, culture and social structures which imply social networks and local environment as enabling factors for cooperation between companies in which trust is a key-element, as is the case of familiar relationships that Porter (1998) considers as a sort of "social glue".

An important guideline in the literature is that human capital and social capital are independent (Florin et al. 2003; Adler, Kwon 2002; Glaeser et al. 2002). Another orientation conceptualises the social capital and human capital of individuals as interdependent and interrelated (Lester et al. 2008), admitting the difficulty in separating their approach, whether at the level of individuals or organisations with aggregate behaviours. In a certain sense, Glaeser et al. (2002) argue that the theoretical basis for assessing the effects of social capital is clear, but through the context of a community and not as individuals. The real owners of social capital, through a network of existing relationships and mechanisms associated with its creation, are not well identified. Moreover, several authors (Dimov, Shepherd 2005; Davidsson, Honig 2003; Pennings et al. 1998; Nahapiet, Ghoshal 1998) found their interrelationships consistent in many aspects, with positive influences on many projects without much knowledge on how they combine. In line with this, Anderson and Miller (2003) showed that human capital and social capital are interrelated in various ways, which causes entrepreneurs endowed with higher levels of human capital to relate to people with similar tastes and influences. In contrast, entrepreneurs from lower socio-economic levels would be disadvantaged in terms of social relationships, more likely to relate to people via limited levels of human capital, which has implications for business and corporate development opportunities. Entrepreneurs with higher levels of human capital, with access to relationships with individuals in prominent positions, achieve higher levels of support for their activities and have higher perceptions of the external context. For example, Xu (1998) has found a positive relationship between human capital and the economic status of individuals.

By virtue of this interdependence and interconnection, data seem to prove the existence of relationships between variables associated with human capital such as knowledge, experience, professional field, cognitive ability and status variables associated with so- 
cial capital such as entanglement, complicity, family support, personal relationships and social relationships. A working hypothesis is as follows:

H1: The elements of human capital, such as knowledge, experience, professional field, cognitive ability and proactivity, are associated with various elements of social capital, such as status, entanglement, complicity, personal relationships, family support and social relationships.

In numerous studies (Pennings et al. 1998; Gimeno et al. 1997), the elements that define features of human capital are found to be important to organisational success, particularly those related to the founders of companies (Colombo, Grilli 2005). These authors argue that individuals with more human capital are more likely to make better business decisions, particularly those individuals with specific human capital based on industry or business experience. Such individuals can take advantage of greater benefits by seizing appropriate business opportunities. Markovic (2008) believes that individual capability is enhanced by higher skill and qualification levels, and this suggest that better human capital would enhance organizational performance. As such, Hambrick and Mason (1984) state that routine activities of managers are influenced by their past experiences and previously established interpersonal relationships.

Dimov and Shepherd (2005) focused on the variables of formal education, industry experience and business experience. They note that in contexts where a high level of human capital predominates, the distinction between areas of educational specialisation may have a greater impact than the number of years of experience or length of education. In turn, Davidsson and Honig (2003) found no positive relationship between years of education and years of experience. Cohen and Levinthal (1990) found that perceptions were influenced by the individual ability that enabled one to accumulate new knowledge, depending on the availability of such stock knowledge formally acquired through training, or implicit knowledge gained through experience in multiple domains. Specifically, one can ascertain the possibility of risk perceptions, opportunities and threats depending on the existence of knowledge and is influenced by the ability to accumulate new knowledge. In summary, the importance of different variables associated with human capital variables for business activity is highlighted by contributions to the success of organisations and by distinguishing multiple variables regarding individuals such as knowledge, experience, professional field, cognitive capacity and action, which all can facilitate social relationships.

People who belong to groups with greater social capital tend to invest more in social relations and accumulate such capital when personal incentives are high, whereby such patterns are not evident if based on a network of interconnections or within the social status (Glaeser et al. 2002). These authors suggest that the status variables regarding relevant forms of individual social capital allow some people to obtain greater benefits from voluntary non-commercial operations. It appears that members of families of high status enjoy great benefits from social recognition. By contrast, members of lower status groups are indifferent or even hostile to prevailing practices, which explains why they are more open to rule changes and shareholder regulations, while displaying lower interest in anything that relates to strengthening the status quo (Phillips, Zuckerman 2001). 
For more educated individuals with social advantages and more group involvement, there is greater diversification of entanglement (Erickson 2004), which is characteristic of broader social structures and in turn promotes cultural diversity and knowledge about different forms of cultural or popular status (Lin 1999; Erickson 1996). Holt (1998) considers culture as an important social advantage that facilitates access to education, jobs and social networks. Experimental results show that the learning of social interlinking is longer when relations of non-social interlinking or trafficking are developed (Janicik, Larrick 2005), which is why the degree of social integration between individuals will affect their ability to correctly understand its context, with implications on their ability to generate social capital.

Burt (2000) reviews the literature and states that entanglement, reputation or status, personal relationships and complicity are four sources of social capital. Its origin lies in the structure and content of social relationships between individuals, centred on personal family relationships and sympathetic friendships as well as social relationships derived from positions of economic, cultural or social influences. Another source of family relationships is based on results, such as emotional attachment, identification and sharing among members.

Adler and Kwon (2002) and Baker (2000) found that investment in interlinking relationships increased individual social capital by promoting the obtainment of benefits via information, power and solidarity of both individuals and groups. Coleman (1988) suggested that new experiences create human capital and that social capital was essential for the reproduction of human capital.

Social capital is defined as social structures and relationships between individuals within organisations. According to Lin (1999), Burt (2000), Adler and Kwon (2002), among others, the goodwill created by the social relationship is derived from family, friends, co-workers and other committed relationships, which provide access to valuable resources that can be mobilised to facilitate decision-making.

Given the importance of normative behaviours in relationships, several authors (Adler 2001; Adler, Kwon 2002) show that relationships are based on trust, reciprocity, obligations and expectations. Tsai (2000) believes that social capital in the organisational context involves the recognised amount of social interlinking between individuals. Hence, high levels of confidence in relationships arise from social interactions, which contribute to the creation of social capital for entrepreneurial learning and new business opportunities (Gabarro 1978; Lechner, Dowling 2003). As entrepreneurs interact with other entrepreneurs, banks and other entities, they theoretically are well positioned to develop trusting relationships that are conducive to the creation and development of new business.

The social relations of differentiated groups with high degrees of mutual interdependence and interrelated activities can strengthen overall social influence (Anderson, Miller 2003). Resources are more prone to be distributed preferentially among members of a group with a common identity (Kramer 1991), especially when they are friends (Aron et al. 1991), when they are demographically similar (Tsui et al. 1992) or when they 
perform interdependent tasks (Greenburg 1979). As such, entrepreneurs often make decisions based on advice from friends and other acquaintances, which is especially relevant for small businesses (Bruderl, Preisendorfer 1998; Paxton 1999; Bennett, Robson 1999). It is recognised, however, that emotional ties provide additional information and can contribute to efficiency gains, which can supplant threats of censorship, ensure the reciprocity of commitment and lead to the exploration of new opportunities, all with lower opportunity costs (Shane, Venkataraman 2000). In summary, the literature indicates that that certain characteristics of social capital are strongly oriented towards the protection (i.e. complicity, family support and family entanglement) usually associated with businessmen, as well as the exercise of power and influence (i.e. status, non-family interlinking, personal relationships and social relationships) usually characteristic of managers. The following two specific hypotheses are established:

H1a: The elements of human capital that are associated with entrepreneurs are related to elements of social capital marked by family protection and complicity.

H1b: The elements of human capital associated with managers are related to elements of social capital marked by power and influence.

In general, case studies of companies across various business sectors are used to analyse relationships between the variables of human capital and social capital, specifically regarding variables that influence relationships between the variables. Doing so can confound the results (Bates 1995). Hence, it is important to investigate each business activity.

Being an entrepreneur is a product of one's social environment. Anderson and Miller (2003) suggest that perceived opportunities are influenced by social origin, and in turn, businesses are likely to be influenced by social capital. The types of experiences in commercial, management and other business settings significantly influence entrepreneurial activities, especially when the specific industry sector is controlled for in the analysis (Bates 1995; Gimeno et al. 1997). Pennings et al. (1998) acknowledged that human capital was specific to certain homogeneities in a given industry sector, which led Dimov and Shepherd (2005) to measure the influence of such sectors on variables associated with human capital.

These studies show the importance of a company's business sector in influencing the relationships between the variables related to human and social capital. The following general and specific hypotheses are established:

H2: Different business sectors or industries influence different relationships between variables associated with human and social capital.

H2a: The elements of human capital associated with entrepreneurs, across different industries, are linked with elements of social capital such as family protection and complicity.

H2b: The elements of human capital associated with managers, across different industries, are linked with elements of social capital such as power and influence. 


\section{Data and methodology}

This research focuses on small- and medium-sized firms (SME) in Portugal across various business sectors such as manufacturing, construction and public works, wholesale trade, retail trade and services, excluding banks and insurance companies. The selected firms were firms which employ fewer than 250 persons and which have an annual turnover not exceeding EUR 50 million, and/or annual balance sheet total not exceeding EUR 43 million (SME definition adopted by European Commission, 2003/361/EC).

The data were collected using a questionnaire that was sent to a group of firms randomly selected from a Dun and Bradstreet database. The chosen firms had between three and fifteen years of business history, specifically because such a duration best captures the evolutionary phases of business projects. The questionnaire included a cover letter, addressed to the general manager of each firm, explaining the purpose of the study and assuring confidentiality. Two weeks after the initial survey mailing, each manager was phoned and encouraged to complete the questionnaire. A total of 199 useable responses were received. Of these, 59 (29.7\%) were from manufacturing companies, 33 (16.6\%) were from construction and public works firms, $45(22.6 \%)$ were from wholesale and retail trade firms, and $62(31.1 \%)$ were from service firms. All of the variables were measured on a 5-point Likert-type scale ranging from 1 (less important) to 5 (more important).

Respondents to the questionnaire were of two types, top managers and business owners. Survey respondents were asked to indicate how much influence various measures of human and social capital had on the performance of the company. A total of 41 variables were considered. Of these, 18 were human capital variables, and 23 were social capital variables. Human capital was measured using five conceptual dimensions (knowledge, experience, professional proficiency, cognitive ability and proactivity), and social capital was measured using six conceptual dimensions (status, interlinking, complicity, personal relations, family support and social relations). Table 1 presents a summary of the dimensions and variables. Descriptive statistics (mean and standard deviation) are also reported in this table.

To enable improved analysis of the results regarding variables of human capital described in this study, factors most likely to characterise the manager and entrepreneur profiles were assessed. There is no rigid separation to determine such categories, but certain factors were seen to favour each type of profile. No company leader is solely an entrepreneur or exclusively a manager. Often, there is a prevalence of certain profile trends, which leads to the characterisation of the manager-entrepreneur or the entrepreneur-manager. The literature is not conclusive in relation to such factors of characterisation. To support such factors, a specific questionnaire was designed for the same group of companies. We obtained a sample of 87 valid responses. The variables were measured using a 7-point scale ranging from -3 ("manager") to +3 ("entrepreneur"), where 0 corresponded to "both". To determine statistically significant differences between "manager" and "entrepreneur", we used a t-test. Fourteen specific variables corresponded to knowledge, experience, professional field, cognitive ability and proactivity. 
Table 1. Human capital and social capital survey items and descriptive statistics (mean and standard deviation)

\begin{tabular}{|c|c|c|c|c|}
\hline \multicolumn{2}{|c|}{ Conceptual dimensions } & Variables & Mean & S.d. \\
\hline \multirow{20}{*}{$\begin{array}{l}\text { Human } \\
\text { capital }\end{array}$} & \multirow[t]{4}{*}{ Knowledge } & Academic level of the chairman & 4.11 & 1.50 \\
\hline & & Academic level of the director/manager & 3.79 & 1.43 \\
\hline & & Specific training of the chairman & 2.21 & 0.81 \\
\hline & & Specific training of the director/manager & 2.13 & 0.85 \\
\hline & \multirow[t]{6}{*}{ Experience } & Business experience & 4.14 & 0.67 \\
\hline & & Management / leadership experience & 4.04 & 0.76 \\
\hline & & Technical / technological work experience & 4.09 & 0.76 \\
\hline & & Commercial work experience & 4.02 & 0.77 \\
\hline & & Industry experience & 3.79 & 1.09 \\
\hline & & Diversified experience & 3.86 & 0.84 \\
\hline & \multirow{3}{*}{$\begin{array}{l}\text { Professional } \\
\text { proficiency }\end{array}$} & Professional proficiency in a & 3.99 & 0.83 \\
\hline & & technical/technological area & 4.07 & 0.77 \\
\hline & & Professional proficiency in company management & & \\
\hline & \multirow{4}{*}{$\begin{array}{l}\text { Cognitive } \\
\text { ability }\end{array}$} & Strategic decision-making regarding & 2.97 & 0.86 \\
\hline & & risk-taking propensity & 3.71 & 0.77 \\
\hline & & Ability to innovate & 3.53 & 0.69 \\
\hline & & Perception of risks and threats & & \\
\hline & \multirow[t]{3}{*}{ Proactivity } & Discovery and exploitation of opportunities & 3.33 & 0.89 \\
\hline & & Widespread knowledge & 3.45 & 0.73 \\
\hline & & Communication skills & 3.70 & 0.86 \\
\hline \multirow{23}{*}{$\begin{array}{l}\text { Social } \\
\text { capital }\end{array}$} & \multirow[t]{4}{*}{ Status } & Economic status & 3.55 & 0.76 \\
\hline & & Cultural status & 3.52 & 0.75 \\
\hline & & Popularity status & 2.96 & 1.00 \\
\hline & & Political status & 2.39 & 1.05 \\
\hline & \multirow[t]{5}{*}{ Interlinking } & Family interlinking & 3.49 & 0.90 \\
\hline & & Work interlinking & 3.47 & 0.80 \\
\hline & & Sporting interlinking & 2.70 & 1.10 \\
\hline & & Associative interlinking & 2.69 & 1.04 \\
\hline & & Political interlinking & 2.28 & 1.04 \\
\hline & \multirow[t]{3}{*}{ Complicity } & Interpersonal solidarity & 3.79 & 0.87 \\
\hline & & Interpersonal confidence & 3.93 & 0.88 \\
\hline & & Understanding of weaknesses & 3.71 & 0.87 \\
\hline & \multirow{5}{*}{$\begin{array}{l}\text { Personal } \\
\text { relations }\end{array}$} & Personal relations with financial entities & 3.41 & 0.94 \\
\hline & & Personal relations with the government & 2.27 & 1.06 \\
\hline & & Personal relations with business associations & 3.02 & 1.05 \\
\hline & & Personal relations with sports associations & 2.58 & 1.11 \\
\hline & & Personal relations with cultural institutions & 2.67 & 1.06 \\
\hline & \multirow{2}{*}{$\begin{array}{l}\text { Family } \\
\text { support }\end{array}$} & Family encouragement regarding challenges & 3.48 & 0.88 \\
\hline & & Family support to overcome difficulties & 3.25 & 0.95 \\
\hline & \multirow{4}{*}{$\begin{array}{l}\text { Social } \\
\text { relations }\end{array}$} & Informal relations with bank/insurance managers & 3.14 & 1.04 \\
\hline & & Informal relations with the government & 1.99 & 1.02 \\
\hline & & Informal relations with business managers & 2.53 & 1.00 \\
\hline & & Informal relations with cultural institutions & 2.49 & 1.01 \\
\hline
\end{tabular}


Data and results of the test of significance are presented in Table 2. The statistical results suggest that managers were characterised by factors such as management experience/ leadership, experiences in technical work, diverse professional experiences, field of business management/leadership, coordination of dispersed knowledge in the firm and ability to communicate within a company. Entrepreneurs were characterised by factors such as business experience, propensity for risk, innovative capacity and discovery and exploitation of business opportunities. Using the literature, a variable associated with comprehension of technical work was added to the manager profile, and a variable associated with risk perception was added to the entrepreneur profile.

Table 2. Test of significance for the differences between "Manager" and "Entrepreneur"

\begin{tabular}{lcccc}
\hline \multicolumn{1}{c}{ Variable } & Manager & Entrepreneur & Both & $p$-value \\
\hline Business experience & & $\mathbf{0 . 4 6 0}$ & $\mathbf{0 . 0 0 1}$ \\
\hline Management/leadership experience & $\mathbf{- 0 . 4 7 1}$ & & $\mathbf{0 . 0 0 4}$ \\
\hline Technical/technological work experience & $\mathbf{- 0 . 4 2 5}$ & & $\mathbf{0 . 0 4 8}$ \\
\hline Commercial work experience & & -0.115 & 0.535 \\
\hline Industry experience & $\mathbf{- 0 . 3 1 0}$ & & 0.034 & 0.854 \\
\hline Diversified experience & & & $\mathbf{0 . 0 3 7}$ \\
\hline $\begin{array}{l}\text { Professional proficiency in a } \\
\text { technical/technological area }\end{array}$ & & & 0.161 & 0.401 \\
\hline $\begin{array}{l}\text { Professional proficiency in company } \\
\text { management }\end{array}$ & $\mathbf{- 0 . 4 0 2}$ & & $\mathbf{0 . 0 2 2}$ \\
\hline $\begin{array}{l}\text { Strategic decision-making regarding } \\
\text { risk-taking propensity }\end{array}$ & & $\mathbf{1 . 1 2 6}$ & $\mathbf{0 . 0 0 0}$ \\
\hline Ability to innovate & & $\mathbf{0 . 7 2 4}$ & $\mathbf{0 . 0 0 0}$ \\
\hline Perception of risks and threats & & 0.092 & 0.571 \\
\hline Discovery and exploitation of opportunities & & $\mathbf{0 . 8 1 6}$ & $\mathbf{0 . 0 0 0}$ \\
\hline Widespread knowledge & $\mathbf{- 0 . 4 1 4}$ & & $\mathbf{0 . 0 2 4}$ \\
\hline Communication skills & $\mathbf{- 0 . 3 7 4}$ & & $\mathbf{0 . 0 1 0}$ \\
\hline
\end{tabular}

Notes: The variables were measured using a 7-point scale ranging from -3 ("Manager") to +3 ("Entrepreneur"), where 0 corresponded to "both". We used a t-test of $H_{0}: \mu_{\mathrm{M}}-\mu_{\mathrm{E}}=0$ versus the two-side alternative $H_{1}: \mu_{\mathrm{M}}-\mu_{\mathrm{E}} \neq 0$. Significant values are indicated in bold

The data collected allowed us to define the entrepreneur as a person with skills to develop business, with competitive and innovative sense, especially qualified to take the risk of uncovering and exploiting new opportunities for the development of the company. Manager refers to a person with leadership skills and coordination, with great understanding and ability to apply the techniques of work organization, with expertise and management experience, particularly skilled in communication and mobilization of expertise aimed at results. According to Watson (1995), entrepreneurs and managers behave a little differently. Managers focus more on doing what is necessary to maintain 
and improve the organizations while entrepreneurs are more likely to quickly recognize new opportunities to seek a constant sense of doing something new and ensuring success. It is not intended to open discussion on this topic because it is recognized are different points of view. As an example we point to the work of Kecharananta and Baker (1999) for whom an entrepreneur is the person who created his own organization and that runs it day-to-day, and they consider the manager as the individual employee with managerial skills.

Factor analysis was used to analyse the data. Factor analysis attempts to describe the structure of a data set and identify clusters of interrelated variables. Factor analysis describes the covariance relationships among the observed variables in terms of smaller numbers of unobserved latent variables called factors. For more details, refer to Everitt and Dunn (2001) and Johnson and Whichern (2007).

Let $Y_{1}, Y_{2}, \ldots, Y_{p}$ be the set of the observed variables. The factor analysis model assumes the form:

$$
Y_{i}=\theta_{i 1} F_{1}+\theta_{i 2} F_{2}+\ldots+\theta_{i q} F_{q}+u_{i}, \quad i=1, \ldots, p,
$$

where $F_{1}, F_{2}, \ldots, F_{q}$ are unobserved latent variables or common factors, $\theta_{i j}$ is the factor loading of the $i$ th variable on the $j$ th factor, and $u_{i}$ is the error or specific factor of the $i$ th variable. We assume that specific errors are not correlated with each other or with the common factors $F_{1}, F_{2}, \ldots, F_{q}$.

We used the principal component factor analysis method to estimate the factor loadings and communalities, which specifically utilises square multiple correlations as estimates of the communalities to compute the factor loadings. This procedure drops those factors with eigenvalues $<1$. We then performed an orthogonal rotation of the factors using the Varimax method to simplify the factor structure. The goal of this method was to obtain factors with a few large loadings and as many loadings close to zero as possible. Factor loadings greater than 0.4 (in absolute value) were considered significant for factor interpretation purposes (Hair et al. 2006). An acceptable factor solution occurred when all variables had a significant loading on a factor.

\section{Results}

After estimation of the parameters by principal-component factor analysis, we obtained a factor solution for the correlations of the 35 human and capital data variables with KMO (Kaiser-Meyer-Olkin measure of sampling adequacy) scores greater than 0.7. The factor loadings were then transformed using the Varimax rotation. The principal component factor method retained nine factors with eigenvalues $\geq 1$. For interpretation purposes, we only examined the first three factors that accounted for nearly half of the total variance. Table 3 shows the unrotated factor loadings and communalities.

The first factor $(F 1)$ in the unrotated solution accounts for $26.1 \%(9.12 / 35)$ of the total variance and $37.2 \%(9.12 / 24.53)$ of the common variance. The second factor (F2) accounts for $14.3 \%(5.01 / 35)$ of the total variance and $20.4 \%(5.01 / 24.53)$ of the common variance. Finally, the third factor (F3) accounts for $7.1 \%(2.48 / 35)$ of the total variance 
Table 3. Factor analysis for human and social capital data

\begin{tabular}{|c|c|c|c|c|c|c|c|c|c|c|}
\hline Variable & F1 & $\mathrm{F} 2$ & F3 & $\mathrm{F} 4$ & F5 & F6 & F7 & F8 & F9 & Comm. \\
\hline Business experience & 0.44 & 0.43 & & & & & & & & 0.73 \\
\hline Management experience & 0.45 & 0.55 & & & & & & & & 0.75 \\
\hline Technical experience & & 0.40 & & & & & & & & 0.79 \\
\hline Commercial work experience & & 0.49 & & & & & & & & 0.61 \\
\hline Industry experience & & & -0.43 & & & & & & & 0.49 \\
\hline Diversified experience & 0.41 & & -0.43 & & & & & & & 0.69 \\
\hline Technical professional proficiency & & 0.44 & & & & 0.47 & & & & 0.72 \\
\hline Management professional proficiency & 0.49 & 0.55 & & & & & & & & 0.67 \\
\hline Ability to innovate & & 0.52 & & & & & & & & 0.51 \\
\hline Perception of risks and threats & 0.42 & & & & & & & & & 0.50 \\
\hline Widespread knowledge & & & & & & -0.50 & & & & 0.71 \\
\hline Communication skills & & 0.42 & & & & & 0.42 & & & 0.74 \\
\hline Economic status & 0.48 & & & & & & & & -0.43 & 0.73 \\
\hline Cultural status & 0.60 & & & & & & & & & 0.64 \\
\hline Popularity status & 0.62 & & & & & & & & & 0.73 \\
\hline Political status & 0.57 & & & 0.40 & & & & & & 0.71 \\
\hline Family interlinking & 0.40 & & 0.53 & & & & & & & 0.54 \\
\hline Work interlinking & 0.51 & & & & & & & & & 0.61 \\
\hline Sporting interlinking & 0.64 & & & & & & & & & 0.74 \\
\hline Associative interlinking & 0.71 & & & & & & & & & 0.72 \\
\hline Political interlinking & 0.64 & & & & & & & & & 0.74 \\
\hline Interpersonal solidarity & & 0.64 & 0.51 & & & & & & & 0.86 \\
\hline Interpersonal confidence & & 0.71 & 0.45 & & & & & & & 0.85 \\
\hline Understanding of weaknesses & & 0.63 & 0.50 & & & & & & & 0.81 \\
\hline Personal relat. with financial entities & 0.47 & & & -0.49 & & & & & & 0.62 \\
\hline Personal relat. with the government & 0.67 & -0.41 & & & & & & & & 0.73 \\
\hline Personal relat. with business assoc. & 0.67 & & & & & & & & & 0.67 \\
\hline Personal relat. with sports assoc. & 0.69 & & & & & & & & & 0.75 \\
\hline Personal relat. with cultural instit. & 0.75 & & & & & & & & & 0.76 \\
\hline Family encouragement & 0.46 & & & & & & & 0.41 & & 0.75 \\
\hline Family support to overcome difficult. & 0.41 & & & & -0.44 & & & 0.41 & & 0.81 \\
\hline Informal relat. with bank managers & 0.56 & & & -0.48 & & & & & & 0.62 \\
\hline Informal relat. with the government & 0.66 & & & & & & & & & 0.78 \\
\hline Informal relat. with busin. managers & 0.73 & & & & & & & & & 0.70 \\
\hline Informal relat. with cultural institutions & 0.76 & & & & & & & & & 0.74 \\
\hline Eigenvalue & 9.12 & 5.01 & 2.48 & 1.75 & 1.49 & 1.35 & 1.23 & 1.09 & 1.01 & \\
\hline Proportion (\%) & 26.1 & 14.3 & 7.1 & 5.0 & 4.3 & 3.9 & 3.5 & 3.1 & 2.9 & \\
\hline Cumulative (\%) & 26.1 & 40.4 & 47.5 & 52.5 & 56.7 & 60.6 & 64.1 & 67.2 & 70.1 & \\
\hline
\end{tabular}

Notes: Factor loadings less than 0.4 (in absolute value) have been excluded; KMO measure of sampling adequacy $=0.84$ 
and $10.1 \%(2.48 / 24.53)$ of the common variance. The communalities indicate the amount of variance that each variable shares with all other variables in the set. For example, $73 \%$ of the correlation for the business experience variable is accounted for by the nine common factors. All variables (except industry experience, ability to innovate, perception of risks and threats and family interlinking) have communality estimates of $60 \%$ or greater. The overall KMO measure of the sampling adequacy is 0.84 , with a significant Bartlett test of sphericity (p-value $<0.01$ ), which is meritorious for a factor analysis.

Using a threshold of \pm 0.4 to identify significant loadings, we observed that all of the variables in the unrotated solution had a significant loading on a factor. Factor 1 has 25 variables with significant loadings, factor 2 has 12 and factor 3 has 6 . The Varimax rotation did not improve the factor structure, and therefore, the unrotated solution was used to interpret the factors.

Factor 1 links human capital variables such as experience (corporate, management and diverse), professional field (management), and cognitive ability (perception of risks) with social capital variables such as status (economic, cultural, popular and political), interlinking (family, work, sports, associative and political), personal relations (financial institutions, government, business associations, sports associations and cultural institutions), family support (encouragement and support on difficulties) and social relations (bank managers and insurance companies, government, association leaders and cultural institutions). Factor 1 reveals that characteristics of human capital are associated with a predominant profile of a manager of significant status and influential personal and social relationships.

Factor 2 links human capital variables such as experience (business, management, technical work and commercial work), professional field (technical and management), cognitive skills (innovation capacity) and proactivity (communication skills) with positive social capital variables such as complicity (solidarity, trust and understanding) and negative social capital variables such as personal relationship with the government. Factor 2 shows that characteristics of human capital are associated with a predominant profile of an entrepreneur; they are positively linked to situations of complicity and interpersonal understanding and negatively linked to a personal relationship with the government.

Factor 3 negatively links human capital variables such as experience (industry and diversified) with social capital variables such as family entanglement and complicity (solidarity, trust and understanding). Factor 3 shows that less experience in industry is associated with greater family entanglement and professional complicity.

In short, it is clear that managers are generally holders of status and privilege as well as influential personal and social relationships. Entrepreneurs are associated with relationships involving interpersonal complicity.

To ascertain the influence of a firm's area of business on the factor structures of human and social capital, we performed a principal component factor analysis on the correlation matrices for each area of business (e.g. manufacturing, construction, wholesale and retail trade, and services). Table 4 summarises the results of the unrotated factor analysis. 


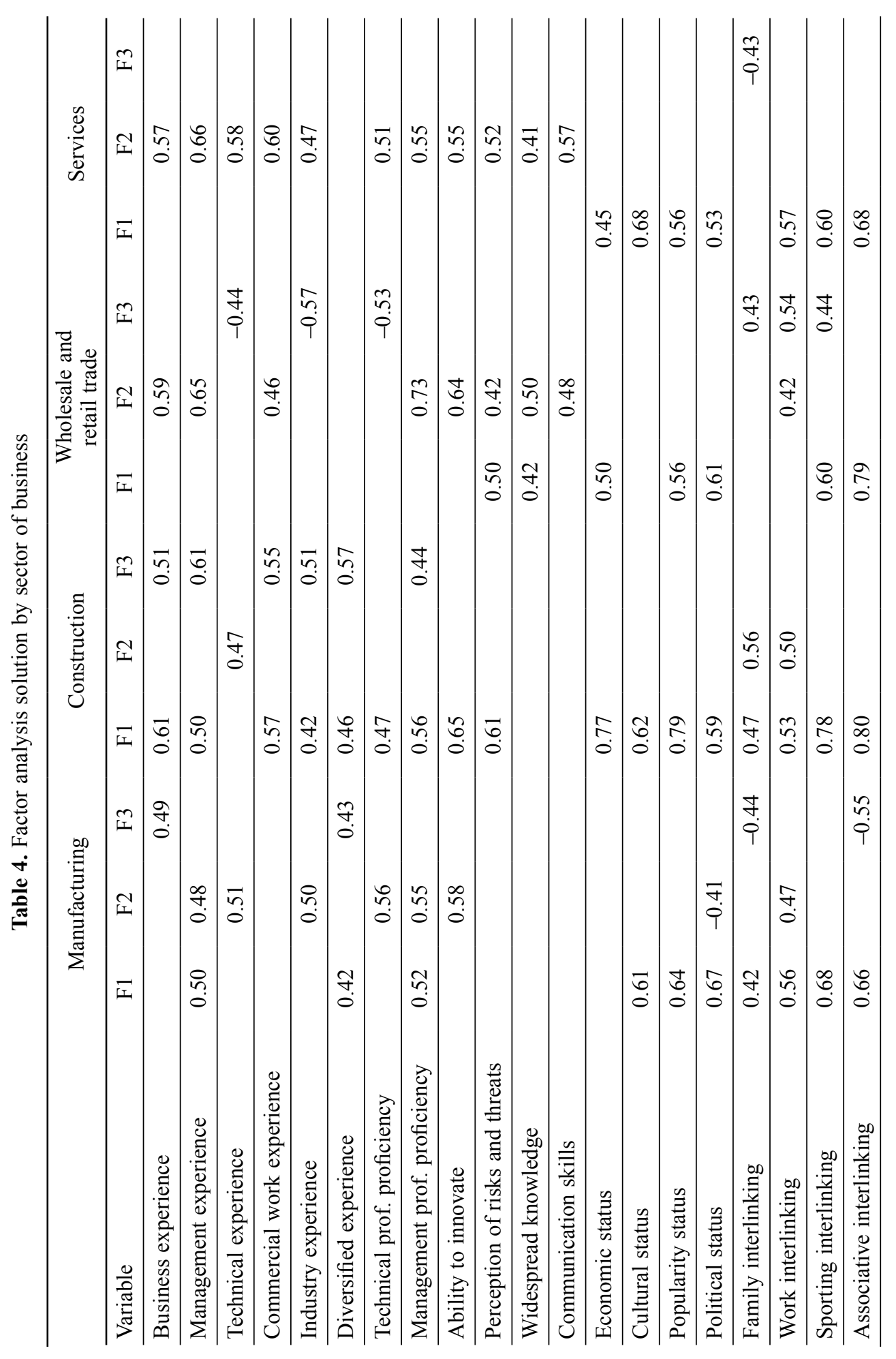




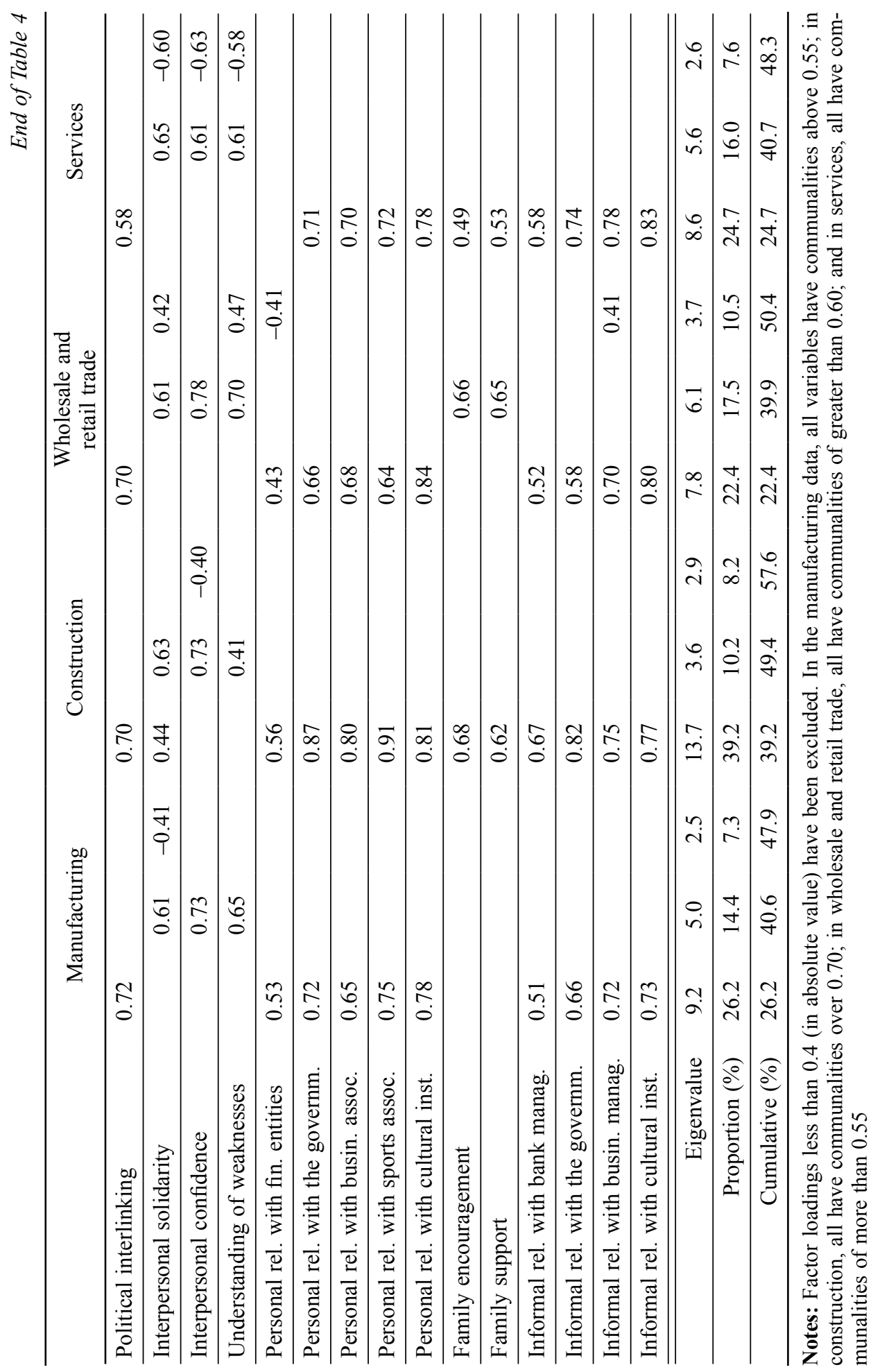




\section{Manufacturing}

In manufacturing, factor 1 is linked to human capital variables such as experience (managed and diversified) and technical field and is also linked to social capital variables such as status (cultural, popular and political), interlinking (family, work, sports, associative and political), personal relationships (financial institutions, government, business associations, sports associations and cultural institutions) and social relationships (bank managers/insurance companies, government, association leaders and cultural institutions). This factor reveals that human capital as a whole is associated with a predominant profile of a manager endowed with positive social status, strong interlinking and significantly influential personal and social relationships.

Factor 2 is linked to human capital variables such as experience (management, technical work and the industry), professional field (technical and management) and capacity for innovation and is also linked to social capital variables such as political status, interlinking of work and complicity (solidarity, trust and understanding). This factor reveals that human capital as a whole is associated with a predominant profile of an entrepreneur who relies significantly on complicity.

Factor 3 is linked to human capital variables such as business and diversified experience and is adversely linked to social capital variables such as family, associative interlinking and interpersonal solidarity. This factor reveals that human capital is associated with an entrepreneur but adversely correlated with reliance on solidarity and family interlinking.

\section{Construction}

In the construction and public works sectors, factor 1 reveals that human capital variables as a whole are associated with the predominant profile of an entrepreneur endowed with strong levels of economic and social status, strong interlinking, family support and significantly influential personal and social relationships. Factor 2 is not linked to characteristics of human capital but is associated with elements of social capital such as complicity, family interlinking and work. Factor 3 reveals that human capital variables as a whole are associated with the predominant profile of a manager who is averse to taking advantages of interpersonal trust.

\section{Wholesale and retail trade}

In the wholesale and retail trade sector, factor 1 reveals that human capital variables such as professional field are sensitive to risk and are associated with the coordination of knowledge related to economic and social status, strong interlinking and intense relationships of personal and social influence. Factor 2 reveals that human capital linked to the profile of an entrepreneur is associated with variables such as complicity and family support. Factor 3 reveals that human capital linked predominantly to the profile of a manager with less experience, less technical expertise and less industry experience and is most associated to variables such as interlinking and complicity.

\section{Services}

In the services sector, factor 1 reveals the importance and independence of social capital variables such as economic and social status, interlinking, family support and personal 
and social relationships. Factor 2 reveals human capital linked predominantly to the profile of an entrepreneur and is especially associated with the variable of complicity. Factor 3 is linked to social capital variables such as complicity (solidarity, trust and understanding) and family interlinking. This shows that most business experience is in contrast to the tendency to resort to complicity and family interlinking.

\section{Discussion}

This study examined the relationship between social capital and human capital. Factor analysis identified three distinct factors of human and social capital. One factor clearly showed a predominant profile of a manager characterised by having status, interlinking and influential personal and social relationships. Another factor reflected a predominant profile of an entrepreneur associated with situations of complicity and interpersonal understanding and was adversely linked to a personal relationship with the government. The third factor highlighted, in particular, the adverse relationship between experience in industry and diversified experiences with the interlinking of family, complicity and interpersonal solidarity. Managers are generally individuals of high status, and they emphasise relationships of personal and social influence that correspond to attitudes of power and influence. Entrepreneurs clearly rely on interpersonal complicity relationships such as attitudes related to protection.

There is a certain rationale for the interconnectedness of variables linked to human capital and social capital that different authors have considered worthy of future investigation (Granovetter 1985; Coleman 1988; Nahapiet, Ghoshal 1998; Lester et al. 2008). They have also admitted that it is difficult to separate human and social capital as independent elements. The calculated factors consist of different variables that reflect the distinct business activities and types of firms that form the overall sample, according to the arguments of Woolcock and Narayan (2000) and Putnam (2000). Naturally, social interconnections hold, bind or unite individuals. Both forms of capital can interfere with the adequate characterisation of the social influence of managers as well as entrepreneurs. The present study confirmed this hypothesis. The elements of knowledge and training, intrinsic to managers and entrepreneurs, show no influence on any of the situations, which is in line with the literature (Becker 1993; Gimeno et al. 1997; Pennings et al. 1998).

Management experience, technical or technological experience, diverse expertise, field of management area and communication skills - all factors typically associated with managers - are associated with the elements of status, interlinking, personal relationship and social relationship. Business experience and cognitive capacity, which are typically associated with entrepreneurs, are associated with variables such as family support and complicity. The status elements are in line with the argument presented by Bourdieu (1986), who considered economic status to be of utmost importance and the basis for all other types of status. He showed that these individuals are likely to possess more human capital because they are more prone to social contacts and derive more effective support from the groups with which they identify. It appears that the variables that make up the elements that typify entrepreneurs are interlinked with elements of social capital that 
characterise situations of family protection and complicity. Entrepreneurs perform their activity, focus on the development and results and face continuing challenges with the risks of assets, and this requires ensuring stable support and relationships of complicity, especially in difficult times. Hypothesis 1a is also confirmed. The variables that make up elements that typify managers are related to elements of social capital that characterise situations of power and influence. Managers essentially seek success in their firms and the best returns for their shareholders. This requires that they depend on personal and social relationships, as well as interlinking, to seize opportunities and other facilities for their businesses. They also seek to take advantage of and develop situations of status. Hypothesis $1 \mathrm{~b}$ is confirmed.

Another aim of the study was to assess the role of business activity in the relationship between human and social capital. The test results were different across the aforementioned business sectors (e.g. manufacturing, construction and public works, wholesale and retail trade and services sectors).

When each of the three factors across the four sectors was assessed, it was found that the activity of services is characterised only by social capital variables for factor 1 . In the manufacturing, construction and public works and wholesale and retail trade sectors, there was an association between social capital and human capital variables. Entrepreneurs and managers in companies within the wholesale and retail trade sector, with cognitive ability (risk) and coordination of knowledge, are different from those examined in the other sectors. Companies in the construction and public works, in comparison to others, were similar in their reliance on professional complicity. The heads of firms in the construction and services sectors used family support, which was not observed in the manufacturing and wholesale and retail trade sectors. In turn, companies in the manufacturing and construction sectors clearly relied on the experience and professional mastery of their managers, which was not observed in the wholesale and retail trade and service firms. Hatch and Zweig (2000) found that the effects of cognitive factors were not obvious to business success, although behaviour characteristics of managers contributed to complicity. Cohen and Levinthal (1990) described the importance of perceptions on influencing the ability of individuals to accumulate new knowledge, including their multiple experiences, from where the ability to perceive risk is derived. Friendship, advice from friends and other relationships influence the decision-making process of entrepreneurs, especially for those in small or medium businesses, according to literature (Bruderl, Preisendorfer 1998; Bennett, Robson 1999). With regard to factor 2 , the heads of industrial firms resort to political status, while those of wholesale and retail trade companies rely on family support, both of which are elements that differentiate them from the construction and services sectors. In turn, managers in wholesale and retail trade and services firms resort to coordination of knowledge and ability via communication, unlike managers in the manufacturing and construction sector firms. Concerning factor 3, in companies with industrial and service activities, managers with greater business experience do not like situations of family interlinking and complicity. In the construction and public works sectors, managers with business mastery and extensive experience were averse to enhancing interpersonal trust. In the wholesale and 
retail trade sector, less control and technical experience and less experience in industry led to greater efforts in interlinking and complicity. In summary, there were clear differences across sectors regarding the human capital characteristics of businessmen (entrepreneurs) and managers associated with characteristics of social capital. These results confirm hypothesis 2 .

Regarding the elements that identify entrepreneurs and managers, as well as their interconnections with elements of social capital, the predominance of the manager profile especially gifted in terms of social status, strong interlinking and significantly influential personal relationships was found in the manufacturing sector. The businessman profile was prone to relying on complicity, political status and interlinking work associated with complicity. In the construction and public works sectors, the entrepreneur, gifted with economic and social status, strong interlinking, family support and strong relations of personal and social influence, were associated with power, influence, protection and complicity, as well as technical work experiences associated with elements of complicity, family interlinking and work. In addition, the entrepreneur was averse to taking advantage of interpersonal trust. In the wholesale and retail trade firms, the managers endowed with economic and social status, strong interlinking and significantly influential personal and social relationships were associated with power and influence. The entrepreneurs relied on family protection and complicity. Managers with less experience, less technical expertise and less industry experience relied on complicity and interlinking. In the service sector, companies stood out predominantly by the independence of social capital compared to human capital, characterised by strong ties between economic status and social status, interlinking, family support and personal and social relations. The entrepreneurs especially relied on complicity in their strong propensity for action. Interestingly, more business experience was inversely related to reliance on complicity and family interlinking.

Large businesses are endowed, in particular, with technical and commercial work experiences and competence in the coordination of knowledge, which are in line with Colombo and Grilli (2005), who investigated business leaders with experience in such areas. Davidsson and Honig (2002) noted strong relationships as sources of additional social capital, which occur between very similar persons (Tsui et al. 1992) sharing a common identity (Kramer 1991). The data obtained were relevant to understanding how a social network affects a manager's ability to recognise and seize opportunities (Anderson, Miller 2003), better access different economic resources and establish different interlinking strategies (Lechner, Dowling 2003; Witt 2004). In turn, entrepreneurs are endowed, in particular, with protection, family support and complicity, which are adopted as a means for protection. This is based on trust, reciprocity, obligations and expectations (Lochner et al. 1999; Adler 2001; Adler, Kwon 2002). All of these behaviours contribute to the creation of cognitive social capital (Tsai 2000), although trust may have an uncertain social nature (Glaeser et al. 2000). Other authors (Coleman 1988; Burt 2000; Adler, Kwon 2002; Anklam 2002) note that social relations are derived from the combination of relations, interpersonal trust, family, friends, co-workers and other committed relationships, which are all influenced by context (Widén-Wulff, Ginman 
2004). Family interlinking is also essential for the reproduction of human capital. In summary, the relationship between human capital variables and social capital variables can be differentiated by identifying entrepreneurs who rely on family protection and complicity, which confirms hypothesis $2 \mathrm{a}$, and managers who hold power and influence, which in turn confirms hypothesis $2 b$.

\section{Conclusions}

The present study demonstrates that head entrepreneurs with a natural propensity to rely on complicity and family protection are different from managers endowed with power and influence based on status, interlinking, personal relationships and social recognition. The training of entrepreneurs and managers has no influence on elements of social capital.

The companies in different business sectors vary in their association with human capital and social capital variables that predominantly typify the actions of either the entrepreneur or the manager. The data reveal that firms in different sectors show clear differences (i.e. manufacturing, construction and public works, wholesale and retail trade and services sectors). Entrepreneurs were generally associated with complicity and, in some cases, family support, while managers were associated economic status, social status, strong interlinking, intense personal relationships and social influence.

This work demonstrates the existence of different interrelationships of variables associated with human and social capital. It also distinguishes the differences between influences of social capital associated with entrepreneurs versus managers.

Future studies are warranted to study firms in other sectors, with different levels of economic development and different legal frameworks. Such studies can assess the presence of elements that can also characterise the profiles of managers and entrepreneurs. In addition, an analysis of interdependence and causality relationships between the dimensions of social capital and human capital as well their influences on company performance will be important.

\section{References}

Adler, P. 2001. Market, hierarchy, and trust: the knowledge economy and the future of capitalism, Organization Science 12: 215-34. http://dx.doi.org/10.1287/orsc.12.2.215.10117

Adler, P.; Kwon, S. 2002. Social capital: prospects for a new concept, Academy of Management Review 27: 17-40.

Anderson, A. 2000. Paradox in the periphery: an entrepreneurial reconception, Entrepreneurship \& Regional Development 12: 91-10. http://dx.doi.org/10.1080/089856200283027

Anderson, A.; Miller, C. 2003. Class matters: human and social capital in the entrepreneurial process, Journal of Socio-Economics 32: 17-36. http://dx.doi.org/10.1016/S1053-5357(03)00009-X Anklam, P. 2002. Knowledge management: the collaboration thread, Bulletin of the American Society for Information Science and Technology 28(6): 1-8.

Aron, A.; Aron, E.; Tudor, M.; Nelson, G. 1991. Close relationships as including other in the self, Journal of Personality and Social Psychology 60: 241-253.

http://dx.doi.org/10.1037/0022-3514.60.2.241 
Baker, W. 2000. Achieving Success Through Social Capital: Tapping Hidden Resources in Your Personal and Business Networks. San Francisco: Jossey Bass, Inc.

Bantel, K.; Jackson, S. 1989. Top management and innovation in banking: does the composition of the top team make a difference?, Strategic Management Journal 10: 107-124.

http://dx.doi.org/10.1002/smj.4250100709

Bates, T. 1995. Self-employment entry across industry groups, Journal of Business Venturing 10: 143-156. http://dx.doi.org/10.1016/0883-9026(94)00018-P

Becchetti, L.; Rossi, S. 2000. The positive effect of industrial district on the export performance of Italian firms, Review of Industrial Organization 16: 53-68.

http://dx.doi.org/10.1023/A:1007783900387

Becker, G. 1964. Human Capital. Chicago: University of Chicago Press.

Becker, G. 1993. Human Capital: a Theoretical and Empirical Analysis. Chicago: University of Chicago Press.

Bennett, R.; Robson, P. 1999. The use of external business advice by SME's in Britain, Entrepreneurship and Regional Development 11: 155-80. http://dx.doi.org/10.1080/089856299283245

Bond, M. H. 1991. Chinese values and health: a cross-cultural examination, Psychology and Health: an International Journal 5: 137-152. http://dx.doi.org/10.1080/08870449108400417

Bourdieu, P. 1986. The forms of capital, in Richardson, J. G. (Ed.). Handbook of Theory and Research for the Sociology of Education. New York: Greenwood Press, 241-258.

Brinlee, J.; Bell, J.; Bullock, C. 2004. Educating entrepreneurs on angel venture capital financing options, Journal of Business and Entrepreneurship 16: 141-156.

Bruderl, J.; Preisendorfer, P. 1998. Network support and the success of newly founded businesses, Small Business Economics 10: 213-225. http://dx.doi.org/10.1023/A:1007997102930

Bruderl, J.; Preisendorfer, P.; Ziegler, R. 1992. Survival chances of newly founded organizations, American Sociological Review 57: 227-42. http://dx.doi.org/10.2307/2096207

Brusco, S. 1982. The Emilian model: productive decentralization and social integration, Cambridge Journal of Economics 6: 167-184.

Brush, C.; Greene, P.; Hart, M. 2001. From initial idea to unique advantage: the entrepreneurial challenge of constructing a resource base, Academy of Management Executive (Special issue on Strategic Management and Entrepreneurship) 15: 64-80.

Burt, R. 1992. Structural Holes: the Social Structure of Competition. Cambridge: Harvard University Press.

Burt, R. 1997. The contingent value of social capital, Administrative Science Quarterly 42: 339352. http://dx.doi.org/10.2307/2393923

Burt, R. 2000. The network structure of social capital, in Sutton, R.; Staw, B. (Eds.). Research in Organizational Behavior 22. Greenwich CT: JAI Press.

Cohen, W.; Levinthal, D. 1990. Absorptive capacity: a new perspective on learning and innovation, Administrative Science Quarterly 35: 128-152. http://dx.doi.org/10.2307/2393553

Coleman, J. 1988. Social capital in the creation of human capital, American Journal of Sociology 94: 95-120. http://dx.doi.org/10.1086/228943

Coleman, J. 1990. Foundations of Social Theory. Cambridge, Massachusetts: Harvard University Press.

Colombo, M.; Grilli, L. 2005. Founder's human capital and the growth of new technology-based firms: a competence-based view, Research Policy 34: 795-816.

http://dx.doi.org/10.1016/j.respol.2005.03.010

Davidsson, P.; Honig, B. 2003. The role of social and human capital among nascent entrepreneurs, Journal of Business Venturing 18: 301-331. http://dx.doi.org/10.1016/S0883-9026(02)00097-6 
De Wever, S.; Martens, R.; Vandenbempt, K. 2005. The impact of trust on strategic resource acquisition through interorganizational networks: towards a conceptual model, Human Relations 58: 1523-1543. http://dx.doi.org/10.1177/0018726705061316

Degenne, A.; Forsé, M. 1999. Introducing Social Networks. London: Sage.

Dimov, D.; Shepherd, D. 2005. Human capital theory and venture capital firms: exploring "home runs" and "strike outs", Journal of Business Venturing 20: 1-21.

http://dx.doi.org/10.1016/j.jbusvent.2003.12.007

Durlauf, N.; Fafchamps, M. 2005. Social Capital: Handbook of Economic Growth. P. Aghion; S. N. Durlauf. Elsevier.

Erickson, B. 1996. Culture, class, and connections, American Journal of Sociology 102: 217-251. http://dx.doi.org/10.1086/230912

Erickson, B. 2004. The distribution of gendered social capital in Canada, in Flap, H.; Volker, B. (Eds.). Creation and Returns of Social Capital: A New Research Program. London: Routledge, 27-50.

Everitt, B. S.; Dunn, G. 2001. Applied Multivariate Data Analysis. New York: Oxford University Press.

Florin, J.; Lubatkin, M.; Schulze, W. 2003. A social capital model of high-growth ventures, Academy of Management Journal 46: 374-384. http://dx.doi.org/10.2307/30040630

Fukuyama, F. 1995. Social capital and the global economy, Foreign Affairs 74(5): 89-103.

http://dx.doi.org/10.2307/20047302

Gabarro, J. 1978. The development of trust, influence, and expectations, in Athos, A. G.; Gabarro, J. J. (Eds.). Interpersonal Behaviors: Communication and Understanding in Relationships. Englewood Cliffs, NJ: Prentice-Hall, 290-303.

Gimeno, J.; Folta, T.; Cooper, A.; Woo, C. 1997. Survival of the fittest? Entrepreneurial human capital and the persistence of underperforming firms, Administrative Science Quarterly 42: 750-783. http://dx.doi.org/10.2307/2393656

Glaeser, E.; Laibson, D.; Sacerdote, B. 2002. An economic approach to social capital, The Economic Journal 112: 437-458. http://dx.doi.org/10.1111/1468-0297.00078

Glaeser, E.; Laibson, D.; Scheinkman, J.; Soutter, C. 2000. Measuring trust, Quarterly Journal of Economics 65: 811-846. http://dx.doi.org/10.1162/003355300554926

Granovetter, M. 1985. Economic action and social structure: the problem of embeddedness, American Journal of Sociology 91: 481-510. http://dx.doi.org/10.1086/228311

Greenburg, J. 1979. Group versus individual equity judgements: is there a polarisation effect?, Journal of Experimental Social Psychology 15: 504-512.

http://dx.doi.org/10.1016/0022-1031(79)90012-X

Gulati, R. 1999. Network location and learning: the influences of network resources and firm capabilities on alliance formation, Strategic Management Journal 20: 397-420.

http://dx.doi.org/10.1002/(SICI)1097-0266(199905)20:5<397::AID-SMJ35>3.0.CO;2-K

Hair, J. F. Jr.; Black, W. C.; Babin, B. J.; Anderson, R. E.; Tatham, R. L. 2006. Multivariate Data Analysis. 6th ed. New Jersey: Prentice Hall.

Hambrick, D.; Mason, P. 1984. Upper echelons: the organization as a reflection of its top managers, Academy of Management Review 9: 193-206.

Hatch, J.; Zweig, J. 2000. What is the stuff of an entrepreneur, Ivey Business Journal 65(2): $68-72$.

Hite, J. 2003. Patterns of multidimensionality among embedded network ties: a typology of relational embeddedness in emerging entrepreneurial firms, Strategic Organization 1: 9-49.

Hofstede, G. 1991. Cultures and Organizations: Software of the Mind. London: McGraw-Hill. 
Holt, D. 1998. Does cultural capital structure American consumption?, Journal of Consumer Research 25: 25-79. http://dx.doi.org/10.1086/209523

Huisman, D. 1985. Entrepreneurship: economic and cultural influences on the entrepreurial climate, European Research 13: 10-17.

Janicik, G.; Larrick, R. 2005. Social network schemas and the learning of incomplete networks, Journal of Personality and Social Psychology 88: 348-364.

http://dx.doi.org/10.1037/0022-3514.88.2.348

Johnson, R.; Wichern, D. 2007. Applied Multivariate Statistical Analysis. 6th ed. New Jersey: Prentice-Hall.

Kecharananta, K.; Baker, H. 1999. Capturing entrepreneurial values, Journal of Applied Social Psychology 29(4): 820-833. http://dx.doi.org/10.1111/j.1559-1816.1999.tb02027.x

Kilduff, M.; Tsai, W. 2003. Social Networks and Organizatons. London: Sage Publications.

Klein, K.; Kozlowski, S. 2000. Multilevel Theory, Research, and Methods in Organizations. San Francisco: Jossey Bass.

Kosnik, R. 1990. Effects of board demography and directors' incentives on corporate greenmail decisions, Academy of Management Journal 33: 129-150. http://dx.doi.org/10.2307/256355

Kramer, R. 1991. Intergroup relations and organizational dilemmas: the role of categorisation processes, in Straw, B. M.; Cummings, L. L. (Eds.). Research in Organizational Behaviour, 13. JAI Press, Greenwich, CT, 1191-1228.

Lazerson, M. 1995. A new Phoenix? Modern putting-out in the Modena knitwear industry, Administrative Science Quarterly 40: 34-59. http://dx.doi.org/10.2307/2393699

Leana, C.; Van Buren, H. 1999. Organizational social capital and employment practices, Academy of Management Review 24: 538-555.

Lechner, C.; Dowling, M. 2003. Firm networks: external relations as sources for the growth and competitiveness of entrepreneurial firms, Entrepreneurship \& Regional Development 15: 1-26. http://dx.doi.org/10.1080/08985620210159220

Lester, R.; Hillman, A.; Zardkoohi, A.; Cannella, A. 2008. Former government officials as outside directors: the role of human and social capital, Academy of Management Journal 51: 999-1013. http://dx.doi.org/10.5465/AMJ.2008.34789675

Lin, N. 1999. Social networks and status attainment, Annual Review of Sociology 25: 467-487. http://dx.doi.org/10.1146/annurev.soc.25.1.467

Lin, N.; Ensel, W.; Vaughn, J. 1981. Social resources and strength of ties: structural factors in occupational status attainment, American Social Review 46: 393-405.

http://dx.doi.org/10.2307/2095260

Lochner, K.; Kawachi, I.; Kennedy, B. 1999. Social capital: a guide to its measurement, Health and Place 5: 259-270. http://dx.doi.org/10.1016/S1353-8292(99)00016-7

Markovic, M. R. 2008. Managing the organizational change and culture in the age of globalization, Journal of Business Economics and Management 9: 3-11.

http://dx.doi.org/10.3846/1611-1699.2008.9.3-11

McNaughton, R.; Bell, J. 1999. Brokering networks of small firms to generate social capital for growth and internationalization, Global Strategic Management 7: 63-82.

http://dx.doi.org/10.1016/S1064-4857(99)07057-6

Mincer, J. 1974. Schooling, Experience and Earnings. New York: Columbia University Press.

Morris, M.; Davis, D.; Allen, J. 1994. Foresting corporate entrepreneurship: cross-cultural comparisons of the importance of individualism versus collectivism, Journal of International Business Studies 25: 65-89. http://dx.doi.org/10.1057/palgrave.jibs.8490849 
Nahapiet, J.; Ghoshal, S. 1998. Social capital, intellectual capital, and the organizational advantage, Academy of Management Review 23: 242-266.

Oh, H.; Chung, M.-O.; Labianca, G. 2004. Group social capital and group effectiveness: the role of informal socializing ties, Academy of Management Journal 47: 860-875.

http://dx.doi.org/10.2307/20159627

Oh, H.; Labianca, G.; Chung, M.-O. 2006. A multilevel model of group social capital, Academy of Management Review 31: 569-582. http://dx.doi.org/10.5465/AMR.2006.21318918

Paxton, P. 1999. Is social capital declining in the United States? A multiple indicator assessment, American Journal Sociology 105: 88-27. http://dx.doi.org/10.1086/210268

Pennings, J.; Lee, K.; Witteloostuijn, A. 1998. Human capital, social capital, and firm dissolution, Academy Management Journal 41: 425-440. http://dx.doi.org/10.2307/257082

Peterson, R. 1988. Understanding and encouraging entrepreneurship internationally, Journal of Small Business Management 26(2): 1-7.

Phillips, D.; Zuckerman, E. 2001. Middle-status conformity: theoretical restatement and empirical demonstrations in two markets, American Journal of Sociology 107: 379-429.

http://dx.doi.org/10.1086/324072

Porter, M. 1998. Clusters and the New Economics of Competition. Harvard Business School Press, November-December, 77-90.

Portes, A. 1998. Social capital: its origins and applications in modern sociology, Annual Review of Sociology 24: 1-24. http://dx.doi.org/10.1146/annurev.soc.24.1.1

Portes, A.; Sensenbrenner, J. 1993. Embeddedness and immigration: notes on the social determinants of economic action, American Journal of Sociology 98: 1320-1350.

http://dx.doi.org/10.1086/230191

Putnam, R. 2000. Bowling Alone: the Collapse and Revival of American Community. New York: Simon \& Schuster.

Putnan, R. D. 1995. Bowling alone: America's declining social capital, Journal of Democracy 61: $65-78$.

Pyke, F.; Sengenberger, W. (Eds.). 1992. Industrial Districts and Local Economic Regeneration. Geneva, International Institute for Labour Studies, ILO. http://dx.doi.org/10.1353/jod.1995.0002

Scheinberg, S.; MacMillan, C. 1986. An 11-country Study of Motivations to Start a Business. Frontiers of Entrepreneurship Research. Wellesley, MA. Babson College.

Schwartz, S. H. 1990. Individualism-collectivism: critique and proposed refinements, Journal of Cross-Cultural Psychology 21: 139-157. http://dx.doi.org/10.1177/0022022190212001

Seibert, E.; Kraimer, L.; Liden, R. 2001. A social capital theory of career success, Academy of Management Journal 44: 219-237. http://dx.doi.org/10.2307/3069452

Shane, S.; Venkataraman, S. 2000. The promise of entrepreneurship as a field of research, Academy of Management Review 25: 217-226.

Tiessen, J. H. 1997. Individualism, collectivism, and entrepreneurship: a framework for international comparative research?, Journal of Business Venturing 12(5): 367-384.

http://dx.doi.org/10.1016/S0883-9026(97)81199-8

Triandis, H. C. 1993. Collectivism and individualism as cultural syndromes, Cross-Cultural Research 17: 155-180. http://dx.doi.org/10.1177/106939719302700301

Tsai, W. 2000. Social capital, strategic relatedness and the formation of interorganizational linkages, Strategic Management Journal 21: 925-939.

http://dx.doi.org/10.1002/1097-0266(200009)21:9<925::AID-SMJ129>3.0.CO;2-I 
Tsai, W.; Ghoshal, S. 1998. Social capital and value creation: the role of intrafirm networks, Academy of Management Journal 4: 464-477. http://dx.doi.org/10.2307/257085

Tsui, A.; Egan, T.; O’Reilly, C. 1992. Being different: relational demography and organizational attachment, Administrative Science Quarterly 37: 549-579. http://dx.doi.org/10.2307/2393472

Van Dijk, M.; Sverrisson, A. 2003. Enterprise clusters in developing countries: mechanisms of transition and stagnation, Entrepreneurship Regional Development 15(3): 183-206.

http://dx.doi.org/10.1080/08985620210159239

Walker, G.; Kogut, B.; Shan, W. 1997. Social capital, structural holes and the formation of an industry network, Organization Science 8: 109-125. http://dx.doi.org/10.1287/orsc.8.2.109

Wasserman, S.; Faust, K. 1994. Social Network Analysis: Methods and Applications. Cambridge: Cambridge University Press.

Watson, C. H. 1995. Directions for Entrepreneurship Research: Viewpoints of Academics. Unpublished doctoral dissertation. South Africa: University of Pretoria.

Widén-Wulff, G.; Ginman, M. 2004. Explaining knowledge sharing in organizations through the dimensions of social capital, Journal of Information Science 30(5): 448-458.

http://dx.doi.org/10.1177/0165551504046997

Witt, P. 2004. Entrepreneurs, networks and the success of start-ups, Entrepreneurship and Regional Development 16(5): 391-412. http://dx.doi.org/10.1080/0898562042000188423

Wolfe, D.; Gertler, M. 2004. Clusters from the inside and out: local dynamics and global linkages, Urban Studies 41(5/6): 1071-1093. http://dx.doi.org/10.1080/00420980410001675832

Woolcock, M.; Narayan, D. 2000. Social capital: implications for development theory, research, and policy, World Bank Research Observer 15(2): 225-250.

$\mathrm{Xu}$, B. 1998. A reestimation of the Evans-Jovanovic entrepreneurial choice model, Economics Letters 58: 91-95. http://dx.doi.org/10.1016/S0165-1765(97)00255-3

J. Augusto FELÍ́CIO. Dr J. Augusto Felício is Assistant Professor at the School of Business and Economics (ISEG), Technical University of Lisbon. He is President of Centre of Management Studies and Research Fellow at the Centre for Advanced Research in Management (ADVANCE) at the School of Business and Economics, Technical University of Lisbon. He holds a PhD in Management from the School of Economics and Management, Technical University of Lisbon. He is author of several articles in scientific journals and international conferences. His research interests are in the areas of entrepreneurship, family firms, human capital and social capital, corporate governance and strategy.

Eduardo COUTO. Dr Eduardo Couto received his PhD in Business Administration from the Manchester Business School, University of Manchester (United Kingdom). He is Assistant Professor and Research Fellow at the Centre for Advanced Research in Management (ADVANCE) at the School of Business and Economics, Technical University of Lisbon. He is author of several papers in international conferences. His current research interests are in the areas of entrepreneurship, financial analysis, banking, portfolio theory and international finance.

Jorge CAIADO. Dr Jorge Caiado is Assistant Professor at the School of Business and Economics (ISEG), Technical University of Lisbon and Researcher at the Centre for Applied Mathematics and Economics, Technical University of Lisbon. He received his $\mathrm{PhD}$ in Mathematics Applied in Economic and Management from the School of Business and Economics, Technical University of Lisbon (Portugal). He was visiting researcher at the Department of Statistics of Carlos III University of Madrid (Spain), 2004. He is the author of more than 50 articles in scientific journals, international conferences, books and book chapters. His current research interests are in the areas of financial econometrics, quantitative finance, computational statistics, time series analysis, multivariate data analysis and forecasting. 